\title{
STRATEGI CEGAH TANGKAL JARINGAN TERORIS DALAM REKRUTMEN DAN SELEKSI PEGAWAI BARU PERTAMINA HULU ENERGI NUNUKAN COMPANY
}

\author{
Muhammad Roy Urich Kusumawardhana \\ Program Studi Magister Manajemen, Sekolah Tinggi Manajemen PPM, Indonesia \\ mkusumaw16@gmail.com \\ Ningky Sasanti Munir \\ Sekolah Tinggi Manajemen PPM, Indonesia \\ ningkymunir@gmail.com
}

\begin{abstract}
ABSTRAK
Ancaman terorisme saat ini menjadi tantangan yang berat dikarenakan adanya fenomena pelaku teroris justru merupakan bagian dari pegawai perusahaan. Dengan demikian, proses seleksi dan rekrutmen pegawai baru menjadi hal strategis dalam melakukan cegah tangkal masuknya jaringan teroris di perusahaan. PHENC yang merupakan objek vital nasional (obvitnas) dan cucu perusahaan migas, PT Pertamina (Persero), berpotensi menjadi target operasional teroris. Hal ini didasarkan pada keterangan mantan narapidana teroris (napiter) yang diwawancara dalam penelitian ini. Tim teroris telah memiliki data jaringan pipa, sumur dan kilang migas seluruh perusahaan Indonesia. Oleh sebab itu, PHENC perlu memiliki strategi cegah tangkal jaringan teroris dalam rekrutmen dan seleksi pegawai baru. Penelitian ini berjenis penilitian terapan dengan pendekatan kualitatif dan naratif yang mendetail mengenai situasi objek penelitian. Data kualitatif dikumpulkan dengan metode wawancara tertulis terhadap perwakilan manajemen PHENC dengan teknik analisis deskriptif. Hasil analisis menunjukan bahwa saat ini PHENC belum melakukan Background Check dalam proses rekrutmen dan seleksi pegawai baru. Berdasarkan daftar risiko PHENC, rekrutmen dan seleksi tercantum dalam risiko secutity threat. Adapun rancangan strategi cegah tangkal jaringan terorisme pada rekrutmen dan seleksi pegawai baru yang diusulkan terdiri dari tiga bagian: bagian untuk pegawai tetap baru, untuk pegawai outsourcing baru dan penerapan sistem manajemen pengamanan (SMP) secara terintegrasi.
\end{abstract}

Kata kunci:

Terorisme, Rekrutmen dan Seleksi, Manajemen Risiko, Sistem Manajemen Pengamanan

\begin{abstract}
The terrorism threat nowadays is a formidable challenge due to the phenomenon of terrorist perpetrators that are actually part of company employees. Thus, selecting and recruiting new employees process is a strategic matter in preventing the entry of terrorist networks into the company. PHENC which is a national vital object and subsidiary of the oil and gas company, PT Pertamina (Persero), has the potential to become a terrorist operational target. It refers to the statements of the ex-combatants interviewed in this study. The terrorist team have data of pipelines, wells, oil and gas refineries throughout Indonesian companies. Therefore, PHENC needs to have a strategy to prevent the terrorism network in the recruitment and selection of new employees. This study is applied research using qualitative and narrative approach with detailed situation of the research object. Qualitative data were collected by written interview method with PHENC management representatives and using descriptive analysis techniques. The analysis result shows that currently PHENC has not conducted Background Check in the recruitment and selection process of new employees. Based on the PHENC risk register, recruitment and selection are listed as secutity threat risks. The design of the proposed strategy to prevent the terrorism network in recruitment and selection of new employees consists of three parts: part for new permanent employees, for new outsourcing employees and the implementation of integrated security management system (SMS).
\end{abstract}

Keywords:

Terrorism, Recruitment and Selection, Risk Management, Security Management System 


\section{PENDAHULUAN}

Ancaman terorisme di Indonesia menjadi tantangan yang cukup berat saat ini dengan adanya fenomena bahwa beberapa pelaku teroris justru merupakan bagian dari pegawai perusahaan. Disamping itu, pelaku teroris tersebut terkadang tidak masuk dalam jaringan teroris tetapi menjadi pelaku teroris secara mandiri (lone wolve). Tentunya hal tersebut menyulitkan pihak berwenang, dalam hal ini pihak Badan Nasional Penanggulangan Terorisme (BNPT) dan pihak POLRI / TNI untuk mendeteksi bahwa pegawai perusahaan tersebut bagian dari jaringan teroris atau tidak.

Pada kejadian serangan teroris pada tanggal 16 Mei 2018, diduga terdapat pegawai BUMN yang menjadi penyandang dana rencana operasi serangan teroris ke Mapolda Riau yang berhasil digagalkan (Tribunnews, 2018). Selain itu, tempat penyerangan teror tersebut membidik lokasi yang berada di objek vital pemerintahan. Kejadian lainnya adalah serangan teroris ke Hotel JW Mariott dan Ritz Carlton pada Jum'at 17 Juli 2009, dimana salah satu pelaku adalah seorang florist yang telah menjadi pegawai selama kurang lebih 4 tahun di hotel tersebut. Menurut informasi dari
Kadiv Humas Mabes Polri, Irjen Pol Nanan Soekarna, Florist yang bernama Ibrohim tersebut merupakan perencana, pengatur, dan pengontrol pelaksanaan pengeboman di Hotel JW Mariott dan Ritz Carlton (inilah.com, 2009). Akibatnya, peledakan di hotel tersebut telah menewaskan sembilan orang.

Melihat fenomena-fenomena di atas, penanganan terorisme di Indonesia memang menjadi wewenang Badan Nasional Penanggulangan Terorisme (BNPT) serta TNI/Polri. Namun, berdasarkan informasi yang disampaikan oleh Direktur Perlindungan BNPT, Brigjen (Pol) Herwan Chaedar, perlu menjadi perhatian bahwa saat ini BNPT belum memiliki formula khusus untuk proses rekrutmen dan seleksi pegawai BUMN agar tidak termasuk dalam jaringan teroris. Selama ini, BNPT menggunakan data dari Densus 88 dan sumber intelejen lainnya untuk memantau pergerakan jaringan teroris yang telah tercium di dalam perusahaan. Lain halnya dengan BNPT, untuk mencegah operasional teroris, pihak Polisi RI sudah memberlakukan Peraturan Kapolri No. 24/2007 tentang penerapan sistem manajemen pengamanan perusahaan, lembaga dan instansi pemerintah. Peraturan ini sebenarnya bisa dipergunakan 
sebagai pedoman bagi perusahaan, terutama yang bergerak dalam industri objek vital nasional (obvitnas) sebagai upaya untuk meminimalisasi risiko teroris.

PT Pertamina Hulu Energi Nunukan Company (PHENC) merupakan anak usaha PT Pertamina (Persero) yang telah diakuisisi dari Anadarko, perusahaan Amerika Serikat. PHENC termasuk dalam bagian Obvitnas dari PT. Pertamina Hulu Energi (PHE), beroperasi di area Nunukan, Kalimantan Utara yang merupakan daerah perbatasan IndonesiaMalaysia. Menurut Ustadz Ali Fauzy selaku Ketua Yayasan Lingkar Perdamaian (wadah bagi para mantan kombatan/napiter) menyatakan bahwa daerah perbatasan ini juga sering digunakan sebagai lalu lintas teroris dengan tidak menggunakan paspor untuk memasukan dan mengeluarkan para teroris ke Malaysia, Thailand dan Philipina. Ditambah lagi, Ustadz Ali menyampaikan bahwa jaringan teroris dapat merekrut 50 orang baru untuk menjadi teroris aktif dan terlatih dalam waktu satu tahun. Pelatihan tersebut dilakukan di beberapa negara seperti Afghanistan, Moro, Malaysia, dan Indonesia. Selama masa pelatihan, mereka dilatih untuk berdakwah, membaca peta, menggunakan senjata (lethal weapon/bom), taktik perang dan field engineering. Para mantan napiter juga diajarkan dalam penggunaan bom untuk di medan perang, dengan merubah bom-bom pesawat yang tidak meledak, memasang bom ranjau, serta bom yang diperbaharui untuk menjadi senjata serang. Pengetahuan bom mulai dari bumbu dapur, C4, Ammonium Nitrat, hingga TNT.

Menurut Ustadz Ali dalam wawancara yang telah dilakukan, jaringan teroris sudah memiliki data terkait seluruh pipa, sumur, dan kilang migas di Indonesia yang dapat dijadikan objek penyerangan. Data-data tersebut didapatkan dengan membangun jaringan ke dalam perusahaan atau instansi pemerintah. Hal ini dikarenakan para teroris cukup pandai dalam melakukan penyamaran sehingga relatif sulit untuk dideteksi. Mereka dapat dengan sengaja masuk menjadi salah satu pegawai melalui proses rekrutmen dan seleksi yang tidak ketat. Salah satu tujuannya yaitu untuk memiliki akses guna mempermudah melakukan aksi teror mereka. Dengan demikian, hal tersebut tidak menutup kemungkinan untuk terjadi pada PHENC. Jika jaringan teroris masuk ke internal PHENC melalui rekrutmen dan seleksi pegawai baru, 
tentunya hal tersebut akan menimbulkan risiko yang dapat berdampak sangat signifikan untuk kelangsungan perusahaan. Dengan demikian, aktivitas rekrutmen dan seleksi pegawai baru menjadi hal yang strategis untuk melindungi PHENC sebagai obvitnas dari masuknya jaringan teroris ke dalam internal perusahaan. Untuk itu, PHENC perlu memiliki strategi cegah tangkal jaringan teroris dalam rekrutmen dan seleksi pegawai baru. Hal ini terilustrasi pada Gambar 1.

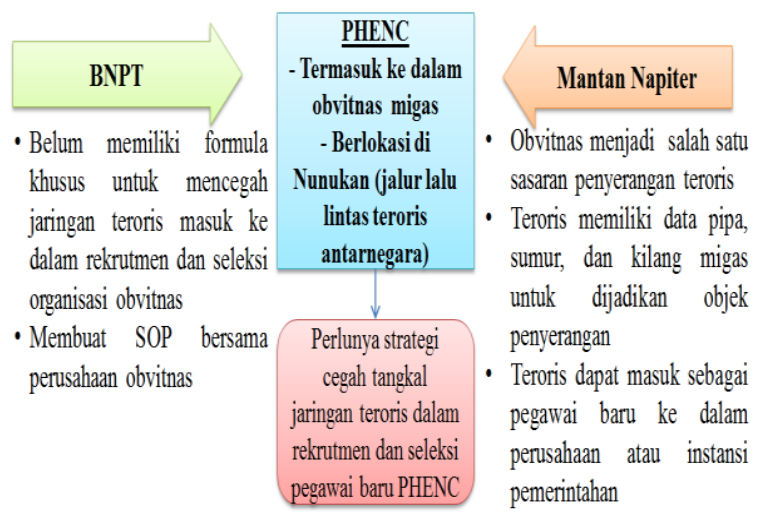

Gambar 1. Urgensi Strategi Cegah Tangkal Jaringan Terorisme Dalam Rekrutmen dan Seleksi Pegawai Baru PHENC

Rumusan masalah dari penelitian ini yaitu bagaimana strategi rekrutmen dan seleksi pegawai baru PHENC saat ini, bagaimana rancangan strategi rekrutmen dan seleksi pegawai baru PHENC yang dapat mencegah jaringan teroris, serta bagaimana implementasi rancangan strategi yang diusulkan. Adapun tujuan dari penelitian ini terdiri dari tiga hal.
Pertama, teridentifikasinya strategi rekrutmen dan seleksi PHENC saat ini. Kedua, tersusunnya rancangan strategi rekrutmen dan seleksi pegawai baru yang dapat mencegah dan menangkal risiko masuknya jaringan teoris dalam PHENC. Ketiga, yaitu tersusunnya langkah implementasi strategi rekrutmen dan seleksi pegawai baru yang dapat mencegah dan menangkal risiko masuknya jaringan teroris ke dalam PHENC

\section{TINJAUANN TEORI \\ PENGEMBANGAN HIPOTESIS}

DAN

Dalam penelitian ini, ada tiga dimensi teori yang digunakan. Pertama yaitu teori terorisme untuk mengetahui karakteristik teroris dan juga pencegahan yang dapat dilakukan. Teori kedua yaitu manajemen risiko sumber daya manusia. Dalam teori ini, dapat diketahui bagaimana pentingnya mitigasi risiko terorisme yang merupakan bagian dari risiko sumber daya manusia dari sebuah organisasi. Teori ketiga yaitu teori strategi rekrutmen dan seleksi. Teori ini digunakan untuk menyusun rancangan strategi cegah tangkal jaringan teroris dalam rekrutmen dan seleksi pegawai baru PHENC. 


\section{Teori Terorisme}

Dalam Undang-Undang Nomor 5 tahun 20018 tentang Pemberantasan Tindak Pidana Terorisme, Bab I Ketentuan Umum, Pasal 1 ayat 2 disebutkan, bahwa terorisme adalah perbuatan yang menggunakan kekerasan atau ancaman kekerasan yang menimbulkan suasana teror atau rasa takut secara meluas, yang dapat menimbulkan korban yang bersifat massal, dan/atau menimbulkan kerusakan atau kehancuran terhadap objek vital yang strategis, lingkungan hidup, fasilitas publik, atau fasilitas internasional dengan motif idiologi, politik atau gangguan keamanan. Sementara itu, ayat 7 menyebutkan bahwa objek vital yang strategis adalah kawasan, tempat, lokasi, bangunan, atau instalasi yang:

a. Menyangkut hajat hidup orang banyak, harkat dan martabat bangsa;

b. Merupakan sumber pendapatan negara yang mempunyai nilai politik, ekonomi, sosial, dan budaya; atau

c. Menyangkut pertahanan dan keamanan yang sangat tinggi.

Czinkota, dkk, (2010) menyatakan bahwa terorisme adalah ancaman terencana, sistematis atau penggunaan kekerasan oleh kelompok-kelompok sub-nasional untuk mencapai tujuan politik, agama, atau ideologis melalui intimidasi dari khalayak luas. Selain itu, Firdaus (2011) mengatakan bahwa karakter teroris berdasarkan hasil studi dan pengalaman empiris dalam menangani aksi terorisme yang dilakukan PBB, antara lain:

a. Teroris umumnya mempunyai organisasi yang solid, disiplin tinggi, militan dengan struktur organisasi berupa kelompokkelompok kecil, dan perintah dilakukan melalui doktrin serta teroris dilatih bertahun-tahun sebelum melaksanakan aksinya.

b. Teroris menganggap bahwa proses damai untuk mendapatkan perubahan sangat tidak disarankan.

c. Teroris memilih tindakan yang berkaitan dengan tujuan politik dengan cara kriminal dan tidak mengindahkan norma dan hukum yang berlaku.

d. Memilih sasaran yang meimbulkan efek psikologi yang tinggi untuk menimbulkan rasa takut dan mendapatkan publikasi yang luas. 
Untuk mencegah terorisme, Czinkota, dkk (2010) menjelaskan bahwa kesiapsiagaan organisasi merupakan hal yang penting. Ini dapat diberikan dengan pedoman langkahlangkah keamanan, teknologi anti-terorisme, dan pendekatan bermanfaat lainnya untuk memastikan sistem organisasi yang vital. Selain itu, Czinkota, dkk (2010) juga menyatakan bahwa manajemen harus memeriksa risiko di seluruh perusahaan dan melakukan perencanaan terhadap pengurangan risiko. Selain itu, pengembangan model manajemen risiko terintegrasi memiliki peran penting dalam pencegahan terorisme (Sheffi, 2005)

Firmansyah (2011) dalam penelitiannya yang berjudul "upaya penanggulangan terorisme di Indonesia" menyatakan bahwa untuk mencegah terorisme, pemerintah telah mengambil beberapa langkah. Langkah pertama adalah meningkatkan keamanan, pengendalian senjata api, sistem transportasi, fasilitas publik, dan sistem komunikasi. Langkah kedua adalah pengawasan bahan peledak dan bahan kimia yang dirakit menjadi bom. Langkah ketiga adalah memperketat kontrol perbatasan dan pintu masuk. Langkah keempat adalah pengawasan komunitas yang mengarah pada aksi teror. Langkah kelima adalah intensifikasi kegiatan kampanye antiterorisme melalui media massa. Dari langkahlangkah tersebut, terlihat bahwa belum ada tindakan yang dilakukan pemerintah untuk mencegah jaringan teroris masuk pada obyekobyek vital nasional.

Kesimpulan dari teori-teori terorisme di atas yaitu terorisme dapat dicegah melalui organisasi yang menjadi target serangan atau dari pemerintah. Dalam konteks organisasi, manajemen keamanan dan manajemen risiko menjadi hal yang penting sebagai upaya dalam mencegah penyerangan teroris.

\section{Manajemen Risiko Sumber Daya} Manusia (SDM)

Risiko merupakan suatu potensi penyimpangan dari sasaran sebagai dampak dari kejadian yang tidak direncanakan (Djohanputro, 2012). Adapun risiko sumber daya manusia didefinisikan sebagai risiko yang terkait dengan pekerja (Maharani, 2018). Dengan demikian manajemen risiko sumber daya manusia dapat diartikan sebagai suatu kegiatan terkoodinir untuk mengelola risikorisiko yang terkait dengan pekerja. Risiko SDM adalah bagian dari risiko operasional 
and Business Review Vol.17, No.2,2020:166-195

bersama dengan risiko produktivitas, manusia memiliki beberapa karakteristik,

teknologi, inovasi, sistem, proses (Djohanputo, 2012). Risiko SDM sangat strategis dalam tingkat operasional perusahaan, hal ini disebabkan SDM perusahaan adalah operator perusahaan untuk mencapai tujuannya. Apabila risiko SDM tidak dikelola dengan baik dan komprehensif maka akan terjadi gangguan operasional perusahaan yang berdampak kerugian perusahaan.

Mitrofanova (2013) menyatakan bahwa manajemen risiko pekerja merupakan suatu proses yang dimulai dari tahap pengembangan strategi sumber daya manusia, mencakup seluruh sistem manajemen sumber daya manusia dari suatu organisasi, termasuk mendefinisikan, menilai dan mengendalikan semua faktor risiko pekerja internal dan eksternal serta perubahan yang dapat berdampak negatif pada kegiatan organisasi dan karyawannya.

Arkhipov \& Abramova (2018) menyebutkan bahwa pengamanan pekerja kerja dan manajemen risiko pekerja memainkan peningkatan peran dalam proses bisnis perusahaan. Huwang, dkk (2017) menyatakan bahwa berdasarkan penelitian lebih lanjut, manajemen risiko sumber daya diantaranya:

a. Objektivitas. Terdapat risiko dalam setiap aspek manajemen sumber daya manusia. Risiko sumber daya manusia ada secara objektif dimana orang-orang hanya dapat mencegah dan menyelesaikan risiko tetapi tidak dapat menghilangkannya. Namun, pasti ada kerugian jika risiko dihilangkan.

b. Dimanis. Frekuensi risiko dalam semua aspek manajemen sumber daya manusia, intensitas dampak pada kegiatan lain dan ruang ruang lingkupnya tidak sama, dan semua ini memiliki karakteristik perubahan dinamis. Karakteristik dinamis dari risiko meningkatkan kesulitan manajemen risiko yang mengharuskan manajemen untuk fokus pada fleksibilitas untuk menghindari kekakuan dan kekekalan.

c. Destruktif. Sumber daya manusia adalah sumber daya perusahaan di mana akan ada risiko dalam proses manajemennya karena itu akan 
menyebabkan kerugian besar bagi perusahaan. Ini tidak hanya akan membahayakan keamanan sumber daya material perusahaan tetapi juga bahkan dapat menyebabkan kegagalan total strategi pengembangan usaha.

Kraev \& Tikhonov (2019) menyatakan bahwa risiko paling sering dalam sistem manajemen SDM perusahaan, yaitu:

a. Risiko pada tahap awal kerja karyawan di perusahaan. Jenis risiko ini muncul ketika mempekerjakan (hiring) karyawan.

Di banyak perusahaan selama prosedur screening tidak dilakukan pemeriksaan kandidat untuk kepatuhan norma sosial, berarti akan ada risiko negatif berupa tindakan pekerja yang berhubungan dengan perusahaan.

b. Risiko saat bekerja dengan karyawan. Kasus khusus adalah ketika sebuah organisasi menjadi "pencari bakat" dan melatih spesialis yang terampil untuk pesaing mereka sendiri.

c. Risiko pada tahap pemutusan kerja dengan karyawan.

Proses rekrutmen adalah bagian dari daftar risiko SDM yang telah di identifikasi oleh perusahaan sebagai bagian dari risiko operasional di tingkat korporat. Menurut Kraev \& Tikhonov (2019), Terdapat beberapa risiko spesifik dalam proses rekrutmen dan seleksi pegawai, diantaranya:

a. Pemilihan kandidat yang salah

b. Kesalahan deskripsi pekerjaan

c. Ketidakakuratan asesmen kandidat

d. Risiko membentuk citra perusahaan yang negatif karena pengumuman yang salah tentang peluang pekerjaan terbuka.

Mitigasi risiko rekrutmen dan seleksi dilakukan secara berjenjang dimulai dari input, proses, dan output dari proses rekrutmen dan seleksi. Menurut Huang, dkk (2017) membuat rencana perekrutan yang baik, memilih cara yang tepat untuk merekrut, untuk memperkuat pelatihan perekrut, transfer staf untuk melakukan optimasi ilmiah dan meningkatkan kualitas rekrutmen perusahaan adalah langkah efektif untuk mencegah risiko sumber daya manusia dari 'pintu masuk'. Rekrutmen adalah pekerjaan paling dasar dalam manajemen sumber daya manusia. 


\section{Strategi Rekrutmen dan Seleksi}

Pengembangan strategi rekrutmen dan seleksi merupakan hal penting untuk mengamankan salah satu aset yang paling berharga dalam organisasi guna mengejar keunggulan bersaing. Untuk mencapai keuanggulan bersaing tersebut, diperlukan pertimbangan yang matang dalam proses rekrutmen dan seleksi. Oleh karena itu, Henderson (2011) menyatakan bahwa proses rekrutmen dan seleksi merupakan proses mayor dalam strategi manajemen sumber daya manusia.

Penyusunan strategi SDM juga dipengaruhi oleh karakteristik strategi bisnis yang digunakan. Menurut Miles \& Snow (1984), terdapat tiga tipologi strategi organisasi, yaitu: defender, prospector, dan analyzer. Berikut merupakan tipologi strategi SDM dalam hal rekrutmen dan seleksi yang merupakan konsekuensi dari strategi bisnis menurut Miles \& Snow (1984).

\section{a. Defenders}

Jenis perusahaan ini menekankan strategi 'building' atau dalam memenuhi sumber daya manusianya. Perusahaan jenis ini menekankan pada strategi "make" dalam rekrutmen, seleksi, dan penempatan karyawan. Oleh karena itu, strategi untuk melakukan rekrutmen pada level manajemen menengah maupun manajemen level atas dilakukan melalui pengembangan kompetensi tenaga kerja dengan program pelatihan dan pengembangan. Dengan demikian, proses rekrutmen dan seleksi dari eksternal ada umumnya hanya untuk memenuhi karyawan pada entry level. Selain itu, seleksi karyawan dilakukan dengan menyingkirkan karyawan yang tidak sesuai dengan kompetensi yang diinginkan.

\section{b. Prospectors}

Jenis perusahaan ini menekankan strategi 'buy' atau 'acquire' dalam memenuhi kebutuhan SDM di organisasi. Oleh karena itu, diperlukan adanya sistem rekrutmen yang canggih sehingga kekosongan posisi dapat diisi oleh karyawan yang berasal dari eksternal perusahaan. Strategi ini juga menekankan pada pemenuhan sumber daya manusia dengan 
kandidat yang telah matang dan siap untuk ditempatkan karena sudah memiliki kompetensi yang dibutuhkan perusahaan. Oleh karena itu, seleksi melibatkan preemployment psycological testing. Dengan demikian, perusahaan tidak memerlukan upaya yang tinggi untuk pelatihan dan pengembangan karyawan.

\section{c. Analysers}

Jenis organisasi ini menggunakan kombinasi dari strategi 'making' dan 'buy'. Akibatnya, proses rekrutmen dan seleksi merupakan gabungan dari kedua strategi tersebut sehingga pendekatan campuran digunakan. Selain itu, pengembangan karyawan tetap dilakukan dan juga penilaian kinerja berorientasi pada proses yang menekankan pada identifikasi kepegawaian dan analisis kebutuhan pelatihan.

\section{Proses Rekrutmen dan Seleksi}

Proses rekrutmen dan seleksi menurut Pergamon Flexible Learning (2007) dalam Snell, S., Morris, S., \& Bohlander, G. (2016) dapat dibagi menjadi 3 bagian yaitu planning, recruitment dan selection. Tahap planning meliputi analisis mengenai urgensi dari recruitment, melakukan job analysis, dan membuat job description, competency profile dan person spesification. Selanjutnya, tahap recruitment terdiri dari menentukan metode apa yang paling cocok dalam melakukan recruitment, bagaimana cara aplikan tertarik untuk melamar dan memasarkan lowongan pekerjaan. Di tahap terakhir, yaitu selection, dimulai dari menyortir aplikasi yang masuk, melakukan wawancara, membuat keputusan dan penawaran dan menghubungi referensi aplikan.

Dengan demikian, kerangka analisis dari penelitian ini adalah sebagai berikut:

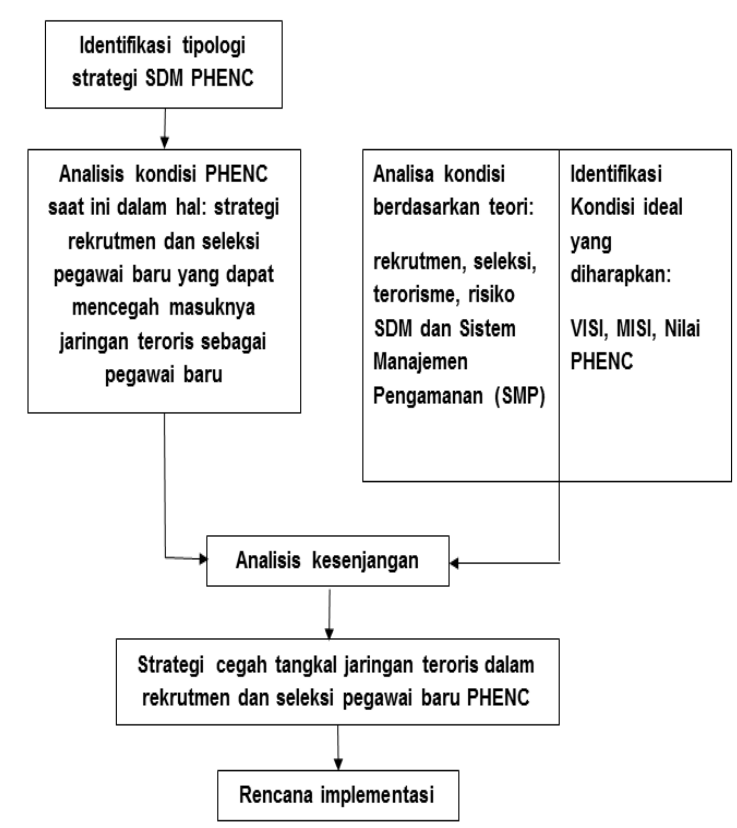

Gambar 2. Kerangka Analis 


\section{METODE RISET}

Penelitian ini berjenis penelitian terapan. Menurut Sekaran dan Bougie (2016), penelitian terapan merupakan penelitian yang dilakukan dalam pengaturan tertentu dengan tujuan spesifik untuk menyelesaikan masalah yang ada dalam situasi tersebut. Saat ini, PT Pertamina Hulu Energi Nunukan Company (PHENC) perlu memiliki strategi cegah tangkal jaringan teroris dalam rekrutmen dan seleksi pegawai baru sebagaimana yang telah dijelaskan pada bagian pendahuluan. Jenis penelitian terapan ini berupa penelitian deskriptif, yaitu penelitian yang menggambarkan variabel dalam sebuah situasi yang menarik bagi peneliti (Sekaran \& Bougie, 2016). Penelitian ini memusatkan perhatian pada pemecahan masalah aktual PHENC dan berfungsi untuk pemecahan masalah praktis dari pengembangan ilmu pengetahuan, yaitu keilmuan manajemen sumber daya manusia, manajemen risiko dan manajemen sistem pengamanan.

Identifikasi strategi rekrutmen dan seleksi PHENC saat ini dilakukan secara kualitatif yang bersifat naratif. Naratif berarti penelitian ini mendetail mengenai situasi pada objek penelitian. Sekaran dan Bougi (2016) menyatakan bahwa data kualitatif merupakan data yang tidak dapat segera dikuantifikasi kecuali dikodekan dan dikategorikan dalam beberapa cara. Data kualitatif ini didapatkan melalui wawancara dengan pihak Departemen Sumber Daya Manusia (SDM) dan karyawan yang pernah mengikuti rangkaian seleksi untuk menjadi karyawan PHENC.

Data yang digunakan dalam penelitian ini terdiri dari dua jenis, yaitu data primer dan data sekunder. Data primer dikumpulkan melalui wawancara tertulis bersama dengan sembilan orang perwakilan PHENC yang berasal dari bagian Human Capital, Security Coordinator, IT Coordinator, Formalities Specialist, Senior Geologist, General Facility Management, dan HSE. Adapun data sekunder dikumpulkan melalui studi dokumen dari SOP rekrutmen dan seleksi PHENC dan website perusahaan.

Secara umum, teknik pengolahan data dalam penelitian ini menggunakan analisis deskriptif untuk mengetahui strategi bisnis yang akan dilakukan perusahaan untuk mencapai sasaran-sasaran PHENC. Hasil wawancara tertulis, dokumen SOP, dan formulir rekrutmen dan seleksi dianalisis 
untuk mengetahui kondisi strategi rekrutmen dan seleksi saat ini yang dapat mencegah jaringan teroris masuk sebagai pegawai baru. Adapun teori terorisme, manajemen risiko SDM, strategi dan proses rekrutmen dan seleksi dipelajari untuk mengetahui bagaimana rancangan strategi rekrutmen dan seleksi yang ideal agar dapat mencegah dan menangkal jaringan teroris masuk ke dalam PHENC serta selaras dengan strategi perusahaan. Validitas hasil wawancara tertulis dari responden diuji dengan metode triangulasi dengan membandingkan kebenaran jawaban dari responden satu dengan responden lainnya.

Analisis kesenjangan dilakukan untuk mengetahui dimensi-dimensi strategi mana saja yang belum sesuai dan perlu penyempurnaan. Hasil analisis kesenjangan selanjutnya digunakan untuk menyusun rancangan strategi cegah tangkal jaringan teroris dalam rekrutmen dan seleksi yang diusulkan untuk PHENC. Terakhir, rancangan strategi rekrutmen dan seleksi yang diusulkan diolah secara deskriptif untuk menyusun implementasi berupa usulan aktivitas atau program terkait strategi rekrutmen dan seleksi PHENC.
HASIL PENELITIAN DAN PEMBAHASAN

\section{Identifikasi Tipologi Strategi SDM}

Untuk menentukan tipologi strategi SDM PHENC, menurut Miles \& Snow (1984), terdapat beberapa aspek yang perlu menjadi pertimbangan. Pertama, ditinjau dari aspek product-market strategy, produk PHENC termasuk ke dalam produk yang stabil, artinya hanya spesifik berupa minyak dan gas. Selain itu, pasar yang dituju juga sudah jelas, yaitu semua orang atau badan yang memakai minyak dan gas. Oleh karena itu, berdasarkan aspek product-market strategy, strategi bisnis PHENC condong ke dalam tipologi defender.

Aspek kedua dan ketiga dilihat dari produksi serta research and development. Dalam aspek ini, PHENC menekankan pada efisiensi di segala lini, optimalisasi produksi dan anggaran biaya investasi, serta pengawasan proyek. Hal tersebut tercantum dalam arah strategi perusahaan. Jenis strategi tersebut identik dengan tipologi defender yang mana dalam aspek research and development, perusahaan mengarah pada perbaikan produk. Selain itu, proses produksi memiliki penekanan pada efisiensi dan rekayasa proses. Dari kedua belas strategi bisnis PHENC, tujuh 
strategi bisnis mengarah ke dalam karakteristik defender, yaitu: efisiensi di segala lini, menaikkan produksi migas, peningkatan lifting, monetisasi gas, percepatan place into service, zero impairment, dan continuous improvement.

Ditinjau dari aspek lain, pemasaran PHENC terbatas hanya dalam hal penjualan. Oleh karena itu, merujuk pada teori Miles \& Snow (1984), semakin kuat bahwa strategi bisnis PHENC mengerucut pada strategi defender.

Berdasarkan dari uraian di atas, dapat disimpulkan bahwa strategi bisnis PHENC memiliki tipologi defender. Oleh karena itu, strategi defender menjadi pilihan PHENC untuk mencapai visi perusahaan, yaitu menjadi "perusahaan minyak dan gas bumi kelas dunia” dengan misi PHENC berupa melaksanakan pengelolaan operasi dan portofolio usaha sektor minyak dan gas bumi dan energi secara profesional dan berdaya laba tinggi yang memberikan nilai tambah bagi pemangku kepentingan.

Strategi bisnis perusahaan memiliki implikasi dalam strategi SDM yang digunakan. Menurut Miles \& Snow (1984), strategi SDM dalam hal rekrutmen, seleksi, dan penempatan, pada perusahaan penganut strategi defender akan menekankan pada strategi "make". Hanya sedikit rekrutmen yang dilakukan untuk karyawan-karyawan level atas. Rekrutmen dan seleksi hanya pada umumnya dilakukan untuk memenuhi kebutuhan karyawan pada tataran entry level. Dengan demikian, proses rekrutmen dan seleksi menjadi hal yang krusial karena beberapa karyawan yang telah direkrut tersebut kelak akan dijadikan sebagai Top Management perusahaan.

Oleh karena PHENC merupakan perusahaan hasil akuisisi dari Anadarco, sebagian besar manajemen merupakan karyawan bawaan dari perusahaan Anadarco. Karyawan-karyawan tersebut merupakan hasil "make" atau bentukan dari perusahaan sebelum akuisisi yang menjadi pegawai tetap internal PHENC. Adapun berdasarkan data pegawai yang ada, pegawai outsourcing PHENC merupakan pegawai kedua terbanyak, yaitu $43 \%$, setelah pegawai tetap internal. Pegawai outsourcing tersebut diperuntukan untuk pekerjaan lapangan atau produksi. Hal ini dikarenakan dengan menggunakan pegawai outsourcing, PHENC dapat menekan biaya operasional. Hal tersebut senada dengan 
strategi bisnis PHENC yang menekankan efisiensi pada setiap lini.

\section{Analisis Strategi Rekrutmen dan Seleksi}

\section{Saat Ini}

Secara umum, proses rekrutmen dan seleksi PHENC saat ini telah sesuai dengan teori rekrutmen dan seleksi menurut Snell, Morris dan Bohlander (2016). Snell, Morris dan Bohlander (2016) menyatakan bahwa dalam proses rekrutmen dan seleksi perusahaan setidaknya ada tiga tahapan yang terdiri dari perencanaan, rekrutmen dan seleksi. Berdasarkan Tata Kerja Organisasi (TKO) Rekrutmen PHENC, tahap perencanaan disebut "Perencanaan Pemenuhan Kebutuhan Pengadaan Pekerja". Inti dari tahap perencanaan yaitu job analysis, dan membuat job description, competency profile dan person spesification. Pada PHENC, job analysis dimulai dengan mengumpulkan data dari setiap manajer fungsi terkait kebutuhan pegawai dan strategic staffing untuk kebutuhan tahun berikutnya. Selanjutnya data tersebut diajukan kepada Human Capital Manager untuk dilanjutkan ke General Manager hingga Direktur melalui proses RJPP. Pada tahap ini, setiap manager fungsi harus mengisi formulir kebutuhan pegawai. Formulir tersebut telah memiliki data yang detail terkait posisi dan spesifikasi pekerjaan serta kualifikasi calon pegawai yang dibutuhkan.

Tahap rekrutmen di PHENC disebut dengan "Pencarian Calon Tenaga Kerja (Talent Sourcing)". Untuk melakukan kegiatan tersebut, PHENC bekerja sama dengan media eksternal yang ditunjuk perusahaan melalui metode pencarian kandididat. Metode pencarian tersebut dilaksanakan secara terintegrasi dengan pilihan media berupa media massa (iklan), website E-recruitment, program kerja sama dengan sekolah, executive search. Dari data tersebut dapat digarisbawahi bahwa rekrutmen pegawai yang terbuka harus disertai dengan proses screening yang baik. Artinya, harus ada tools yang memastikan bahwa pihak eksternal yang direkrut sebagai pegawai baru itu sesuai dengan tatanan nilainilai perusahaan. Demikian juga dikaitkan dengan terorisme di jalur Nunukan, kandidat pegawai baru harus dipastikan tidak terkait dengan jaringan teroris. Rekrutmen eksternal PHENC terdiri dari dua jenis, yaitu fresh graduate dan experience hired. 
Berdasarkan teori yang merujuk pada

Snell, Morris dan Bohlander (2016), tahapan seleksi diawali dengan proses screening. Adapun PHENC melakukan proses screening berupa seleksi administrasi dalam hal nilai IPK, TOEFL dan akreditasi perguruan tinggi untuk fresh graduate. Sementara itu, persyaratan administrasi bagi experience hired hanya berupa minimum periode pengalaman yang relevan serta kemampuan Bahasa Inggris setara TOEFL/TOEIC. Proses screening seperti ini masih belum cukup jika dikaitkan dengan pencegahan masuknya jaringan terorisme. Berdasarkan Undang-Undang No.5 Tahun 2018, terorisme termasuk ke dalam tindakan kriminal sehingga Surat Keterangan Catatan Kepolisian (SKCK) dalam menjadi tools yang baik dalam proses screening. Namun, persyaratan SKCK sebagai salah satu filter dalam seleksi karyawan baru belum dilakukan pihak PHENC.

Menurut Snell, Morris dan Bohlander (2016), tahapan kedua dalam seleksi yaitu wawancara. Hal ini berbeda dengan apa yang dilakukan oleh PHENC yang memilih tes psikologi dan Bahasa Inggris sebagai tahapan setelah screening pertama. PHENC meletakan proses wawancara pada tahap tes psikologi dan Bahasa Inggris. Adapun metode wawancara yang dipakai oleh PHENC berupa panel interview yang terdiri dari fungsi terkait, People Development Committee (PDC) dan Fungsi Human Capital Talent Management (HCTM). Dalam wawancara tersebut, terdapat enam kompetensi yang dinilai, diantaranya: knowledge, skill, attitude and others (KSAO); keterampilan teknis; komunikasi dan kerja tim; inisiatif dan kontribusi; pengembangan diri dan pengembangan orang lain serta kepemimpinan (hanya untuk posisi pemimpin). Dari keenam kompetensi tersebut, aspek KSAO memiliki bobot tertinggi yaitu 4 dibandingkan kelima aspek lainnya yang hanya memiliki bobot 3 .

Tahap seleksi selanjutnya Menurut Snell, Morris dan Bohlander (2016) yaitu post interview screening. Tahap ini dapat dilakukan dengan cara reference check dan background check (BC). Namun, PHENC melakukan tahap ini hanya berupa reference check. Itu pun hanya diperuntukkan bagi experience hired sedangkan bagi fresh graduate tidak ada. Sementara itu, tahapan BC belum dilakukan. Hal ini tentunya menjadi catatan bagi PHENC. Padahal, BC menjadi hal yang penting bagi PHENC untuk memastikan bahwa calon 
pegawai baru memiliki tatanan nilai yang sama dengan perusahaan. Hal ini menjadi kesenjangan yang penulis temukan dari proses seleksi yang dilakukan oleh PHENC.

PHENC melakukan proses preemployment test dengan menggunakan metode psikotest dan tes kesehatan. Hal ini sudah sesuai dengan teori rekrutmen dan seleksi dimana PHENC telah menjalankan preemployment test. Psikotest hanya salah satu dari beberapa metode yang dapat dilakukan untuk menguji calon pegawai baru terkait knowledge, skill, attitude and other characteristics (KSAO) yang mereka miliki.

Berdasarkan keseluruhan rangkaian seleksi yang dilakukan, PHENC belum memiliki validity test. Padahal, validity test cukup penting untuk mengevaluasi apakah proses seleksi karyawan yang dilakukan sudah efektif dan efisien atau belum. Selain itu, metode pengambilan keputusan dalam seleksi yang digunakan oleh PHENC menggunakan pendekatan statistik. Hal ini ditandai dengan adanya bobot yang standar dalam setiap kompetensi yang dinilai saat wawancara.

Proses rekrutmen dan seleksi yang telah dijelaskan di atas hanya berlaku bagi pegawai tetap PHENC. Adapun rekrutmen dan seleksi pegawai outsourcing dikelola oleh perusahaan mitra kerja. Saat ini, pengadaan labour supply untuk pegawai outsourcing hanya berdasarkan kontrak yang disepakati antara PHENC dengan pihak mitra kerja. Belum ada mekanisme khusus untuk memastikan bahwa pegawai outsourcing yang dipakai terbebas dari jaringan terorisme. Hal tersebut menjadi catatan bagi PHENC untuk memastikan bahwa pegawai outsourcing yang bekerja di PHENC terbebas dari jaringan terorisme. Untuk itu, diperlukan mekanisme dan sistem yang jelas untuk menjamin bahwa semua pegawai baru yang masuk di PHENC, baik pegawai tetap, pegawai kontrak, dan pegawai outsourcing sesuai dengan kompetensi yang dibutuhkan PHENC untuk mencapai sasaran perusahaan serta terbebas dari penyusupan jaringan terorisme. Walaupun demikian, PHENC secara prosedur dapat dikatakan sudah memiliki upaya untuk mencegah jaringan teroris masuk sebagai pegawai baru outsourcing. Hal tersebut terlihat dari prosedur pembuatan bagde mitra kerja yang mengharuskan adanya kelengkapan dokumen Surat Keterangan Catatan Kepolisisan (SKCK) dan penelitian khusus (Litsus) dari pegawai baru. Namun, untuk saat ini, hal tersebut 
hanya sebatas untuk keperluan pemenuhan persyaratan dari Departemen QHSSE.

\section{Analisis Manajemen Risiko Dalam}

\section{Rekrutmen dan Seleksi}

Risiko Sumber Daya Manusia (SDM) menjadi hal yang sangat strategis. Hal ini disebabkan risiko SDM memiliki dampak yang signifikan, terutama terkait proses rekrutmen dan seleksi pegawai baru yang terpapar jaringan teroris serta berpotensi merusak perusahaan dari dalam. Untuk menanggulangi hal tersebut, diperlukan upaya mitigasi dengan menerapkan sistem manajemen pengamanan secara terintegrasi dan terpadu oleh semua pihak yang berkepentingan. Pemetaan risiko SDM dalam profil risiko perusahaan harus mempertimbangkan aspek masuknya jaringan teroris ke dalam perusahaan sebagai pegawai, baik permanen, kontrak atau pegawai kontraktor yang memiliki akses ke area-area yang memiliki aset sensitif yang dapat mengganggu jalannya operasi.

Dalam register risiko PHENC, risiko dalam rekrutmen dan seleksi belum menyebutkan adanya penyusupan jaringan teroris sebagai pegawai baru. Padahal berdasarkan wawancara tertulis yang telah dilakukan, pegawai PHENC sepakat bahwa terdapat potensi masuknya jaringan teroris melalui rekrutmen dan seleksi pegawai baru. Selain itu, dalam register risiko PHENC, risiko rekrutmen dan seleksi digolongkan ke dalam risiko berlevel rendah. Hal ini terlihat dari warna hijau yang tertera dalam register risiko PHENC. Padahal, bilamana terjadi aksi terorisme yang dilakukan oleh teroris yang menyusup sebagai PHENC akan memberikan dampak yang sangat signifikan bagi perusahaan.

Mitigasi atau penanganan risiko rekrutmen dan seleksi yang tertulis dalam register risiko berupa background check. Akan tetapi berdasarkan wawancara tertulis, hal tersebut tidak dilakukan kembali.

\section{Ringkasan Analisis Kesenjangan}

Setelah melakukan analisis kondisi rekrutmen dan seleksi PHENC saat ini dalam hal mencegah dan menangkal jaringan teroris masuk sebagai pegawai baru dengan membandingkannya dengan teori-teori terorisme, strategi rekrutmen dan seleksi, serta manajemen risiko SDM, berikut merupakan ringkasan kesenjangan-kesenjangan yang telah 
teridentifikasi:

Tabel 1. Ringkasan Analisis Kesenjangan

\begin{tabular}{|c|c|}
\hline Teori & Kesenjangan \\
\hline \multirow{2}{*}{ Terorisme } & $\begin{array}{l}\text { Pemerintah Indonesia belum } \\
\text { melakukan tindakan } \\
\text { pencegahan masuknya jaringan } \\
\text { teroris terhadap objek-objek } \\
\text { vital nasional }\end{array}$ \\
\hline & $\begin{array}{l}\text { Perlu adanya kesiapan dari } \\
\text { organisasi untuk melakukan } \\
\text { pencegahan terorisme melalui } \\
\text { penerapan manajemen risiko } \\
\text { dan sistem pengamanan }\end{array}$ \\
\hline \multirow{4}{*}{$\begin{array}{c}\text { Strategi } \\
\text { Rekrutmen dan } \\
\text { Seleksi }\end{array}$} & $\begin{array}{l}\text { Belum ada syarat SKCK } \\
\text { sebagai tahapan screening } \\
\text { dalam proses seleksi yang } \\
\text { dapat mencegah jaringan } \\
\text { teroris masuk ke dalam } \\
\text { perusahaan sebagai pegawai } \\
\text { baru }\end{array}$ \\
\hline & $\begin{array}{l}\text { Tidak ada Post-Interview } \\
\text { Screening berupa background } \\
\text { check }\end{array}$ \\
\hline & $\begin{array}{l}\text { Tidak ada validity test untuk } \\
\text { menguji efektivitas proses } \\
\text { seleksi }\end{array}$ \\
\hline & $\begin{array}{l}\text { Belum ada sistem dan } \\
\text { mekanisme untuk menjamin } \\
\text { pegawai outsourcing baru } \\
\text { terbebas dari jaringan } \\
\text { terorisme }\end{array}$ \\
\hline \multirow[b]{2}{*}{$\begin{array}{l}\text { Manajemen } \\
\text { Risiko SDM }\end{array}$} & $\begin{array}{l}\text { Belum menyebutkan jaringan } \\
\text { teroris dalam risiko rekrutmen } \\
\text { dan seleksi }\end{array}$ \\
\hline & $\begin{array}{l}\text { Mitigasi berupa background } \\
\text { check sebagai penanganan } \\
\text { risiko rekrutmen dan seleksi } \\
\text { dalam register risiko tidak } \\
\text { berjalan }\end{array}$ \\
\hline
\end{tabular}

Kesenjangan-kesenjangan yang tertera

dalam Tabel 1 menjadi masukan dalam penyusunan rancangan strategi cegah tangkal jaringan terorisme dalam rekrutmen dan seleksi pegawai baru PHENC. Dalam hal terorisme, pemerintah belum melakukan tindakan pencegahan terhadap masuknya jaringan teroris pada objek-objek vital nasional. Selain itu, kesiapan organisasi berupa manajemen risiko dan sistem pengamanan perlu dibangun sebagai upaya pencegahan terorisme.

Dalam hal strategi rekrutmen dan seleksi, kesenjangan yang terjadi yaitu belum ada syarat SKCK dalam screening seleksi yang dapat mencegah jaringan teroris masuk ke dalam perusahaan sebagai pegawai baru PHENC. Padahal terorisme termasuk ke dalam tindakan kriminal sehingga adanya SKCK dapat menjadi filter awal dalam pencegahan jaringan teroris. Selain itu, tidak adanya proses background check sebagai post interview screening. Kesenjangan berikutnya yaitu belum ada validity test untuk menguji efektivitas proses seleksi. Terakhir, belum adanya sistem dan mekanisme untuk menjamin pegawai outsourcing baru terbebas dari jaringan terorisme.

Adapun dari sisi manajemen risiko SDM, dalam register risiko PHENC belum menyebutkan jaringan teroris dalam risiko rekrutmen dan seleksi. Selain itu, mitigasi yang tertulis dalam register risiko berupa background check sebagai penanganan risiko rekrutmen dan seleksi dalam register risiko tidak berjalan. Kesenjangan-kesenjangan tersebut akan menjadi masukan untuk 
membuat rancangan strategi.

\section{Rancangan Strategi}

Berdasarkan pada hasil analisis yang dikaitkan dengan teori dan kondisi ideal PHENC yang mengacu pada visi misi dan tata nilai, disusun beberapa strategi cegah tengkal jaringan teroris dalam rekrutmen dan seleksi pegawai baru. Konsep rancangan strategi cegah tangkal masuknya jaringan teroris dalam PHENC terdiri dari strategi untuk pegawai baru PHENC dan pegawai baru outsourcing.

\section{Pegawai Baru PHENC}

Usulan rancangan strategi cegah tangkal jaringan teroris dalam rekrutmen dan seleksi pegawai baru PHENC dapat dilihat pada Gambar 3.

Proses rekrutmen dan seleksi diawali dengan planning atau perencanaan. Tahap ini meliputi analisis kebutuhan berdasarkan Human Resource Planning. Setelah itu, dilakukan analisis pekerjaan (job analysis), competency profile dan person spesification terhadap setiap pekerjaan yang akan dilakukan rekrutmen dan seleksi. Tahap kedua yaitu rekrutmen yang dapat bersumber dari internal maupun eksternal. Informasi lowongan kerja pada tahap rekrutmen ini harus sejelas mungkin yang disesuaikan dengan spesifikasi yang telah ditentukan pada saat planning. Hal ini dilakukan agar dalam proses rekrutmen dapat menggiring pelamar untuk melakukan self-selection (Snell, Morris dan Bohlander, 2016) untuk memudahkan proses seleksi. Proses seleksi dilakukan sesuai dengan prosedur dan job qualification dengan memperhatikan aspek keamanan, terutama untuk posisi yang memiliki akses ke aset yang sensitif.
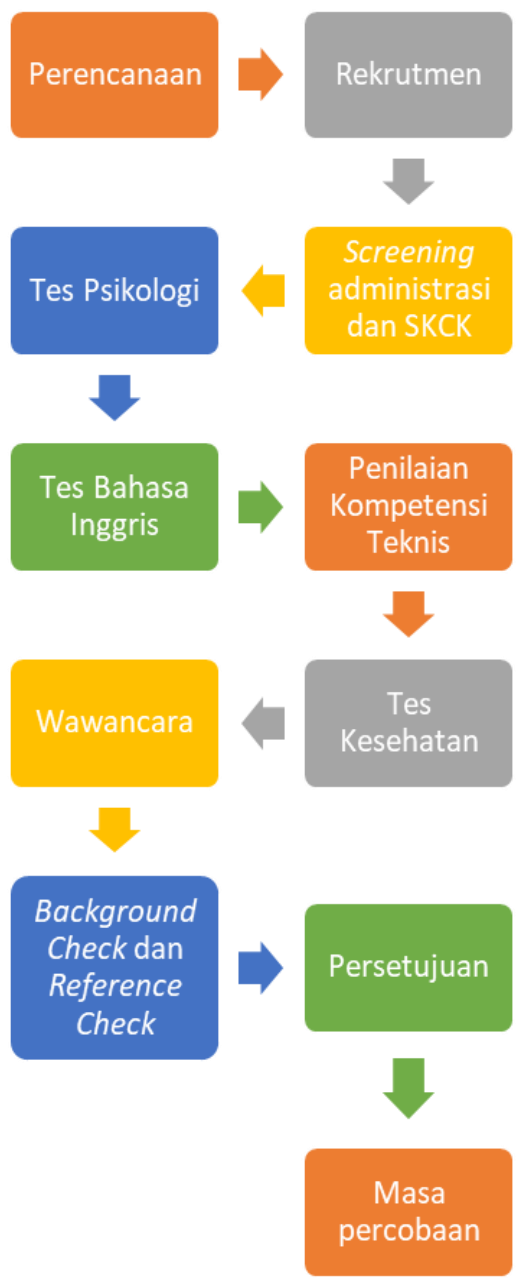

Gambar 3. Rancangan Rekrutmen dan Seleksi Pegawai Baru PHENC 
Usulan tahapan seleksi pegawai baru PHENC yaitu proses screening. Untuk mencegah jaringan teroris masuk sebagai pegawai baru, pihak PHENC perlu menambahkan persyaratan Surat Keterangan Catatan Kepolisian (SKCK) dalam proses screening. Dengan demikian, selain kelengkapan administrasi umum, pegawai baru juga diwajibkan untuk melampirkan SKCK sebagai prasyarat seleksi berikutnya. Berdasarkan Tata Kerja Organisasi (TKO) PHENC, untuk fresh graduate, persyaratan administrasi yang dimaksud berupa nilai IPK, TOEFL, dan akreditasi perguruan tinggi. Adapun untuk experience hired, persyaratan yang dimaksud berupa periode pengalaman yang relevan dan kemampuan Bahasa Inggris setara TOEFL atau TOEIC.

Seleksi berikutnya yaitu berupa preemployment test yaitu melakukan pengujian tertentu untuk mengetahui kompetensi, kognitif, keterampilan, dan hal lainnya. Bentuk pre-employment test dapat berupa psikotest, uji keterampilan atau keahlian, serta medical check up. Untuk memilih pelamar yang akan di terima sebagai pegawai baru, PHENC dapat membandingkan kandidat satu dengan lainnya sesuai dengan job qualification dengan beberapa cara dalam mengambil keputusan. Metode pengambilan keputusan yang diusulkan yaitu dengan statistical approach untuk menjaga hasil seleksi secara objektif. Hasil seleksi kandidat tetap diputuskan melalui rapat komite rekrutmen yang beranggotakan $\mathrm{HR}$, user, dan fungsi recruiter (perekrut). Dalam proses seleksi ini dapat dilihat rekam jejak dan portofolio kandidat sesuai dengan pekerjaan yang dilamarnya.

Selanjutnya, seleksi dilakukan dengan interview tatap muka secara langsung untuk meyakinkan gestur kandidat adalah sesuai dengan tipe pekerjaannya. Metode interview yang diusulkan yaitu situational interview atau behavioral description interview. Dengan kedua metode wawancara tersebut, PHENC dapat menggali pemahaman atau ideologi calon pegawai baru. Jika menggunakan metode situational interview, PHENC yang bertindak sebagai interviewer memberikan sebuah kejadian hipotetik terkait terorisme dan meminta aplikan untuk menanggapi dan memberi respon mengenai kejadian tersebut. Alternatif kedua, bilamana menggunakan wawancara dengan metode behavioral description interview, interviewer dapat 
and Business Review Vol. 17, No. 2, 2020:166-195

menanyakan beberapa pertanyaan tentang

pengalaman yang telah dilalui oleh aplikan

dan apa yang dia lakukan dalam pengalaman

tersebut. Tipe pertanyaan yang digunakan

pada jenis interview ini adalah encouraging

questions.

Setelah tahap wawancara, untuk mencegah tangkah jaringan teroris, perlu ditambahkan proses post interview screening berupa background check dan reference check. Dalam proses background check yang menjadi indikator utama adalah tidak terlibatnya kandidat dengan tindak kriminal. Tahap ini juga dapat dilakukan adalah dengan me-review media sosial dari kandidat atas persetujuan yang bersangkutan. Sebab dari media sosial dapat dilihat bagaimana keseharian dari para kandidat pegawai baru.

Proses seleksi pegawai baru wajib menggunakan proses background check (BC) yang melibatkan pihak yang berwenang, mulai dari penggunaan Surat Keterangan Catatan Kepolisian (SKCK) dari Baintelkam POLRI, hingga melibatkan Badan Nasional Penanggulangan Teroris (BNPT) dan para mantan kombatan/napiter untuk memberikan masukkan yang lebih akurat dan mutakhir terhadap profil kandidat calon pegawai baru
PHENC, terutama untuk area yang memiliki akses ke aset yang sensitif terhadap gangguan operasi. Proses BC dilakukan secara comperehensive mulai dari silsilah keluarga, teman, tetangga, tempat pengajian atau kegiatan agama lainnya, status keuangan apabila posisi strategis, status hukum, status pernikahan, dan informasi lainnya yang relevan.

Untuk menguji validitas seleksi, metoda yang diusulkan yaitu constuct validity. Metode ini merupakan pendekatan untuk mengetahui kepribadian apa yang relevan untuk jenis pekerjaan tertentu dan menguji keakuratan dari tes kepribadian itu sendiri. Dikaitkan dengan terorisme, metode tersebut dipilih karena terorisme berkaitan dengan kepribadian seseorang. Oleh sebab itu, construct validity diperlukan untuk mengevaluasi apakah metode seleksi yang digunakan sudah dapat menangkal jaringan terorisme atau tidak.

\section{Pegawai Outsourcing}

Usulan rancangan strategi cegah tangkal jaringan teroris dalam rekrutmen dan seleksi pegawai outsourcing PHENC dapat dilihat pada gambar berikut ini: 
Perencanaan

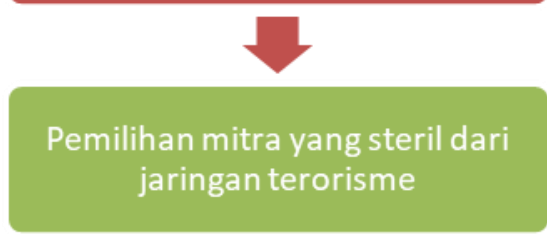

Tata Kelola Rekrutmen dan Seleksi yang memenuhi parameter cegah tangkal jaringan teroris

\section{Gambar 4. Usulan Rekrutmen dan Seleksi Pegawai Outsourcing PHENC}

Usulan rekrutmen dan seleksi untuk pegawai baru outsourcing terdiri dari tiga tahap. Tahap pertama yaitu planning atau perencanaan. Planning dilakukan dengan melakukan analisis kebutuhan pegawai baru outsourcing berdasarkan Human Resource Planning (HRP). Tahap kedua yaitu pemilihan mitra kerja yang sudah streril dari jaringan teroris. Untuk itu, PHENC perlu membuat database terkait mitra kerja mana saja yang terpercaya dan steril. Tahap ketiga yaitu membuat tata kelola rekrutmen dan seleksi yang dapat memenuhi parameter cegah tangkal teroris. Hal yang terpenting dalam tata kelola yang sesuai dengan parameter cegah tangkal teroris yaitu proses Background check (BC) dan persyaratan SKCK. Proses BC wajib diberlakukan kepada semua kandidat, termasuk kandidat pegawai kontraktor yang memasuki area yang memiliki aset yang sensitif terjadinya gangguan. Proses BC dapat dilakukan secara mandiri oleh PHENC dengan melakukan pengecekan media sosial sesuai dengan kesepakatan dari pihak kandidat. Adapun untuk posisi penting dan strategis maka perlu melibatkan pihak berwenang seperti BNPT/POLRI yang memiliki database jaringan teroris di Indonesia. Perlu penelitian lebih lanjut dari hasil BC terutama untuk pegawai yang berada di jobsite Nunukan baik yang direkrut dari Jakarta maupun local hired, baik yang permanen/kontrak atau pegawai kontraktor. Proses screening dapat dilakukan double check pada saat mengambil kartu pass dari Departement Security, hal ini untuk menjamin dan meyakinkan bahwa semua pegawai PHENC tidak termasuk jaringan teroris.

\section{Mitigasi Risiko SDM di Lingkungan PHENC}

Masuknya jaringan teroris ke dalam lingkungan PHENC melalui rekrutmen dan seleksi pegawai dapat menjadi risiko SDM bagi PHENC. Untuk itu, risiko tersebut harus dimitigasi. Proses background check dan 
and Business Review Vol.17, No. 2, 2020 : 166-195

persyaratan SKCK sudah menjadi mitigasi

pertama dalam pencegahan masuknya jaringan

teroris. Akan tetapi, hal tersebut masih belum

cukup. PHENC perlu menerapkan Enterprise

Risk Management (ERM) dan juga Sistem

Manajemen Pengamanan (SMP) secara

terintegrasi. Dengan menerapakan sistem

manajemen pengamanan secara terintegrasi

dengan sistem manajemen perusahaan maka

PHENC telah melakukan upaya mitigasi risiko

keamanan secara korporasi. Adapun risiko

SDM sudah bagian dari kriteria SMP yang

harus dikelola secara konsisten dan holistik

untuk semua pegawai PHENC baik yang

permanen, kontrak, maupun dari kontraktor.

SMP ini bertujuan untuk menjaga agar

perlakuan rekrutmen, BC, seleksi, untuk

pegawai baru terus dilakukan secara

berkesinambungan dan terus mengikuti

perkembangan situasi dan kondisi yang termutakhir

\section{Rencana Implementasi}

Implementasi rancangan strategi cegah tangkal masuknya jaringan teroris sebagai pegawai PHENC harus dilaksanakan dengan penuh kesadaran. Implementasi rancangan harus dilaksanakan secara konsisten, secara kolektif oleh semua stakeholder. Komitmen pimpinan adalah salah satu syarat berhasilnya implementasi strategi cegah tangkal jaringan teroris ini. Oleh sebab itu, pimpinan sebagai pemegang amanah harus memiliki pemahaman dan kesadaran yang baik terhadap ancaman tersebut.

Langkah impelementasi pertama yang dapat dilakukan oleh PT PHENC dalam melaksanakan strategi cegah tangkal jaringan teroris yaitu menetapkan SOP rekrutmen dan seleksi. SOP ini menjelaskan terkait bagaimana proses standar rekrutmen dan seleksi PHENC agar dapat mencegah dan menangkal jaringan teroris. Output dari langkah ini berupa dokumen SOP rekrutmen dan seleksi yang telah disahkan oleh manajemen PHENC. Adapun PIC atau penanggung jawab dari penetapan SOP ini yaitu bagian SDM atau Departement Human Resource (HR).

Langkah implementasi kedua yang dapat dilakukan oleh PHENC yaitu membuat Checklist Background check (BC). Checklist ini harus disesuaikan dengan kebutuhan jenis pekerjaan yang ada di PHENC. Output dari langkah ini berupa dokumen Checklist BC yang telah disahkan oleh manajemen PHENC. 
Adapun PIC atau penanggung jawab dari penetapan SOP ini yaitu bagian SDM atau Departement Human Reource juga Departement Security.

Proses Background check (BC) dapat dilakukan sesuai dengan kebutuhan job specification-nya dan tingkat risiko keamanannya. BC dapat dikatagorikan menjadi 3 (tiga) tingkatan, yaitu: untuk fungsi pendukung bisnis, produksi khusus control room, dan manajemen. Ketiga kategori tersebut memiliki tingkatan $\mathrm{BC}$ yang berbedabeda. ketiga kategori pegawai yang terdiri dari fungsi pendukung bisnis, produksi khusus control room, dan manajemen wajib menyerahkan SKCK sebagai syarat seleksi. Hal ini dikarenakan kegiatan terorisme termasuk ke dalam tindak kriminal sehingga SKCK diperlukan sebagai filter awal untuk memastikan calon pegawai terbebas dari aktivitas terorisme.

Fungsi pendukung bisnis (terdiri dari tiga status: pegawai tetap, kontrak dan outsource) memiliki tingkat Background check (BC) yang paling rendah (1). Hal ini dikarenakan job specification dari kelompok ini memiliki tingkat risiko yang paling rendah diantara dua kelompok lainnya karena akses yang dimiliki dalam hal operasi bisnis relatif terbatas. Untuk itu, BC hanya perlu dilakukan dalam hal keluarga, teman, lingkungan sosial, lingkungan tempat tinggal, dan media sosial. Kategori kedua, yaitu pegawai untuk produksi khusus control room (terdiri dari tiga status: pegawai tetap, kontrak dan outsource) perlu menjalani Background check (BC) yang relatif lebih kompleks (level 2) dibandingkan pegawai untuk fungsi penunjang bisnis. Hal ini dikarenakan pegawai dalam kategori ini memiliki akses ke dalam arean yang sangat vital bagi operasi bisnis PHENC. Dengan demikian, diperlukan perlakuan $\mathrm{BC}$ yang lebih mendalam, meliputi: keluarga, teman, lingkungan sosial, media sosial, tempat bersosialisasi, tempat belajar agama, idola, pemahaman idiologi Indonesia, referensi pekerjaan sebelumnya.

Kategori terakhir yaitu manajemen perlu mendapat perlakuan Background check (BC) yang paling kompleks (level 3). Hal ini dikarenakan manajemen merupakan jabatan yang strategis dalam tataran perusahaan sehingga memiliki tingkat risiko yang tinggi. Oleh sebab itu, BC untuk manajemen terdiri dari: keluarga, teman, lingkungan sosial, media sosial, data pinjaman, data kepemilikan 
and Business Review Vol.17, No. 2, 2020 : 166-195

saham, hobi, tempat bersosialisasi, tempat

belajar agama, idola, pemahaman idiologi

Indonesia, referensi pekerjaan sebelumnya,

LHKPN (Laporan Harta Kekayaan Pejabat

Negara), serta bankruptcy check.

Setelah membuat check list Backgroud

Check, langkah implementasi selanjutnya, yaitu implementasi ketiga berupa bekerja sama dengan pihak berwenang seperti Badan Nasional Penanggulangan Terorisme (BNPT) atau POLRI serta mantan kombatan (jika diperlukan). Hal tersebut untuk memudahkan background check pada saat proses seleksi pegawai baru PHENC. Output dari langkah ini berupa Memorandum of Understanding (MoU) yang telah disahkan oleh manajemen PHENC serta pihak berwenang tersebut. Adapun PIC atau penanggung jawab dari penetapan SOP ini yaitu bagian Departement Security.

Langkah implementasi keempat yang dapat dilakukan oleh PHENC yaitu menentukan kriteria seleksi dengan mempertimbangkan verifikasi rekam jejak untuk memastikan tidak terpapar jaringan teroris. Hal tersebut dilakukan untuk mencegah dan menagkal jaringan teroris masuk pada saat proses seleksi pegawai baru
PHENC. Output dari langkah ini berupa Dokumen Kriteria Seleksi yang telah disahkan oleh manajemen PHENC. Adapun PIC atau penanggung jawab dari penetapan SOP ini yaitu bagian SDM atau Departement Human Resource (HR).

Langkah implementasi kelima yang dapat dilakukan oleh PHENC yaitu memperbaharui register atau daftar risiko SDM sebagai bagian dari risiko operasional menjadi bagian dari risiko yang strategis. Hal tersebut untuk menekankan bahwa proses rekrutmen dan seleksi menjadi proses yang kritis untuk memastikan semua kandidat yang masuk sebagai pegawai baru, termasuk pegawai outsourcing sejalan dengan visi misi serta tata nilai PHENC. Output dari langkah ini berupa Dokumen Daftar Risiko yang telah disahkan oleh manajemen PHENC serta pihak berwenang tersebut. Adapun PIC atau penanggung jawab dari penetapan SOP ini yaitu bagian Departmen Manajemen Risiko, SDM/ Departmen HR dan Departement Security.

Langkah implementasi keenam yang dapat dilakukan oleh PHENC yaitu Membuat database mitra kerja yang steril untuk pegawai outsourcing. Hal tersebut untuk memastikan 
mitra yang bekerja sama dengan pihak PHENC steril dari jaringan teroris serta memiliki tata kelola rekrutmen dan seleksi yang memenuhi parameter cegah tangkal jaringan teroris. Output dari langkah ini berupa Database Mitra Kerja. Adapun PIC atau penanggung jawab dari penetapan SOP ini yaitu bagian SDM atau Departement Human Resource serta Departement Security.

Langkah implementasi ketujuh yang dapat dilakukan oleh PHENC yaitu menerapkan sistem manajemen pengamanan secara terintegrasi dan terpadu untuk menjamin pengendalian risiko keamanan dilakukan dengan menyeluruh. Output dari langkah ini berupa kebijakan, panduan, dan SOP sistem manajemen pengamanan (SMP). Adapun PIC atau penanggung jawab dari penetapan SOP ini yaitu Departement Security.

Langkah implementasi kedelapan yang dapat dilakukan oleh PHENC yaitu pengelolaan database hasil Background check (BC). Output dari langkah ini berupa database rekaman hasil BC. Adapun PIC atau penanggung jawab dari penetapan SOP ini yaitu Departement IT, SDM/HR, dan Departement Security.

\section{KESIMPULAN DAN SARAN}

\section{Kesimpulan}

Hasil analisis dan pembahasan telah dihasilkan tiga kesimpulan, diantaranya. Pertama, strategi PHENC saat ini termasuk dalam strategi defender dimana pegawai PHENC yang ada saat ini sebagian besar merupakan pegawai bawaan sebelum akuisisi dari Anadarko. Adapun proses rekrutmen dan seleksi diawali oleh proses rekrutmen dari pihak eksternal. Tahapan kedua yaitu proses screening dengan mencocokan persyaratan administrasi yang sesuai dengan kebutuhan kompetensi pekerjaan dan kompetensi pelamar. Selanjutnya rekrutmen dan seleksi dilanjutkan dengan pre-employment test berupa psikotest, tes Bahasa Inggris dan tes kesehatan. Setelah itu, tahapan seleksi dilanjutkan dengan melakukan wawancara, offering, persetujuan, masa induksi dan masa percobaan. Dengan demikian, proses rekrutmen dan seleksi pada PHENC saat ini belum melakukan background check (BC). Saat ini pelamar juga belum diwajibkan untuk menyerahkan Surat Keterangan Catatan Kepolisian (SKCK). Selain itu, proses seleksi 
PHENC belum memiliki validity test untuk mengevaluasi efektivitas rangkaian seleksi.

Kedua, rancangan stategi rekrutmen dan seleksi yang dapat mencegah dan menangkal risiko masuknya jaringan teroris ke dalam PHENC secara umum terbagi ke dalam tiga bagian. Bagian pertama diperuntukkan bagi pegawai tetap baru PHENC dengan melakukan Background check yang melibatkan pihak berwenang seperti BNPT, POLRI, atau mantan kombatan serta persyaratan kelengkapan SKCK. Bagian kedua diperuntukkan bagi pegawai outsourcing dari kontraktor berupa pemilihan mitra kerja yang steril dan memiliki tata kelola rekrutmen serta seleksi yang sudah sesuai dengan parameter cegah tangkal teroris. Bagian ketiga mitigasi risiko SDM pada proses rekrutmen dan seleksi dengan menerapkan sistem manajemen pengamanan (SMP) secara terintegrasi dan komprehensif serta penerapan Enterprise Risk Management (ERM) di lingkungan PHENC

$$
\text { Rencana implementasi strategi }
$$

rekrutmen dan seleksi pegawai baru yang dapat mencegah dan menangkal risiko masuknya jaringan teroris ke dalam PHENC terdiri dari delapam langkah. Langkah pertama yaitu menetapkan SOP rekrutmen dan seleksi, dengan menambahkan persyaratan Background check (BC) dan persyaratan SKCK dalam proses rekrutmen. Langkah kedua yaitu membuat Checklist BC disesuaikan dengan kebutuhan jenis pekerjaannya. Langkah ketiga yaitu bekerjasama dengan pihak yang berwenang seperti: BNPT/POLRI dan mantan kombatan (apabila diperlukan). Langkah keempat yaitu menentukan kriteria seleksi dengan mempertimbangkan verifikasi rekam jejak untuk memastikan tidak terpapar jaringan teroris. Langkah kelima yaitu melakukan update daftar risiko khususnya risiko SDM sebagai bagian dari risiko operasional menjadi bagian dari risiko yang strategis. Langkah keenam yaitu membuat database mitra kerja yang steril untuk pegawai outsourcing. Langkah ketujuh yaitu menerapkan sistem manajemen pengamanan secara terintegrasi dan terpadu untuk menjamin pengendalian risiko keamanan dilakukan dengan menyeluruh. Langkah kedelapan yakni pengelolaan database hasil Background check (BC). 
Strategi Cegah Tangkal Jaringan Teroris dalam.... (Muhammad Roy U.K \& Ningky Sasanti M.)

Saran

Dengan menerapkan rancangan

strategi cegah tangkal masuknya jaringan

teroris dalam rekrutmen dan seleksi

pegawai baru, penulis menyarankan agar:

1. PHENC dapat memetakan risiko

SDM sebagai risiko strategis

dengan adanya ancaman

masukanya jaringan teroris

melalui pegawainya.

2. PHENC bekerjasama dengan

BNPT/POLRI untuk melakukan

Background check (BC)

terhadap semua kandidat

pegawai baru sesuai dengan

usulan SOP PHENC.

3. Menerapkan sistem manajemen

pengamanan secara terintegrasi

sebagai langkah pre-emtif,

preventif hingga represif untuk

menghadapi ancaman masuknya

jaringan teroris sebagai pegawai

baru PHENC.

4. Segera menerapkan Background

check untuk semua pegawai baik yang berstatus permanen,

kontrak hingga outsourcing dari

kontraktor/labor supply. Adapun

melakukan BC dapat dilakukan

secara mandiri atau bersama

pihak berwenang terkait hal ini

yaitu BNPT dan atau POLRI

5. Pengelolaan database yang baik dari hasil rekaman $\mathrm{BC}$, seleksi, coaching, counselling dari seluruh pegawai PHENC memudahkan memantau terjadinya perubahan perilaku yang ekstrem, radikal, dan intoleran.

6. Sertifikasi Sistem Manajemen Pengamanan (SMP) untuk mejamin penerapan SMP secara konsisten, comprehensive dan berkesinambungan. Adapun manfaat dari sertifikasi adalah SMP diaudit oleh pihak independen (POLRI) sehingga diharapkan hasilnya akan lebih obyektif dan taat azas. 


\section{DAFTAR PUSTAKA}

Arkhipov, A.A., \&Abramova, O.F. (2018). Modern statisics on the use of social networks of different segments of the population. Materials of X "International Student Forum - 2018". 6.

Czinkota, M. R., Knight, G., Liesch, P. W., \& Steen, J. (2010). Terrorism and international business: A research agenda. Journal of International Business Studies, 41(5), 826-843. doi: 10.1057/jibs.2010.12.

Djohanputro, Bramantyo. (2012). Manajemen Risiko Korporat Terintegrasi. Jakarta: PPM Manajemen.

Firdaus, R. (2011). Terorisme, Isis, Warga Negara Indonesia, Dan Kejahatan Siber. Mimbar Hukum,23, 2nd ser. Retrieved August 18, 2019.

Henderson, I. (2011). Human Resource Management for MBA Students. 2nd edn. London: CIPD.

Huang, W., Sun, Q., Guan, X., Peng, S. (2017) Human Resource Risk Identification and Prevention. Control and System Engineering. 1(1): 16-21

Kraev, V.M., \& Tikhonov, A.I. (2019). Risk Management in Human Resource Management. TEM Journal. 8

Maharani, A.R. (2018). Perancangan Manajemen Risiko Operasional di PT X dengan Menggunakan Metode House of Risk. Tesis. Fakultas Bisnis dan Manajemen Teknologi. Institut Teknologi Sepuluh Nopember.

Miles and Snow C., Organization Strategy, Structure and Processes. 1984

Mitrofanova, A. (2013). Methodological aspects of management of personal risks in the organization. European Science and Technology: 4th International scientific conference, Munich.

Morgan, J. Stephanie (2008). Outsourcing and Human Resource Management: An International Survey. New York: Routledge.

Niqmah, L. (2018, May 16). Fakta-Fakta Serangan Terduga Teroris di Mapolda Riau: Berada di Area Objek Vital Pemerintahan. Retrieved August 15, 2019, from https://wow.tribunnews.com/2018/05/16/fakta-fakta-serangan-terduga-teroris-di-mapolda-riauberada-di-area-objek-vital-

pemerintahan?page=all\&_ga=2.25196990.2096255091.1565840207-2120234212.1565840207

Pergamon Flexible Learning. (2008). Recruitment and Selection Revised Edition. Oxford: Elsevier.

Peraturan Kapolri No.24. (2007). Sistem Pengamanan di Organisasi, Perusahaan, Lembaga/ Instansi Pemerintah.

PT Indonesia News Center. (n.d.). Ibrohim, dari Florist ke Bomber-nasional. www.inilah.com. Retrieved August 16, 2019, from https://m.inilah.com/news/detail/140972/ibrohim-dari-floristke-bomber

Sekaran, U., \& Bougiee, R. (2017). Research methods for business a skill-building approach. Chichester: Wiley.

Sheffi, J. (2005). The resilient enterprise: Overcoming vulnerability for competitive advantage. Boston, MA: MIT Press. Siekman, P. 2003. Protecting America's Ports. Fortune, 10 November: 198. 
Snell, S., Morris, S., \& Bohlander, G. (2016). Managing Human Resources. Canada: Cengage Learning.

Undang-Undang Republik Indonesia Nomor 5 Tahun 2018 Tentang Perubahan Atas Undang-Undang Nomor 15 Tahun 2003 Tentang Penetapan Peraturan Pemerintah Pengganti Undang-Undang Nomor 1 Tahun 2002 Tentang Pemberantasan Tindak Pidanan Terorisme Menjadi UndangUndang. Diakses dari https://sipuu.setkab.go.id/ tanggal 07 April 2020 